\begin{tabular}{|c|c|c|}
\hline \multicolumn{2}{|c|}{ Jurnal Penelitian Pendidikan IPA (JPPIPA) } & \multirow[t]{2}{*}{ (6.6) } \\
\hline P-ISSN : 2 & 1-2582 | E-ISSN $\cdot 2407-795 \mathrm{X}$ & \\
\hline $\begin{array}{l}\text { Sekretaria } \\
\text { Telp./Fax }\end{array}$ & $\begin{array}{l}\text { : Lt. } 3 \text { Gedung Pa } \\
: \text { (0370) } 634918\end{array}$ & \\
\hline Email & :jppipa@unram.ac.id & \\
\hline Website & : http://jppipa.unram.ac.id/index.php/jppipa/index & \\
\hline
\end{tabular}

\title{
THE CHARACTERISTICS OF YAM (Dioscorea Alata) STARCH EDIBLE FILM
}

\section{ULYARTI $^{1}$, E. MARYANA ${ }^{1}$, I. RAHMAYANI ${ }^{1}$, NAZARUDIN ${ }^{1,2 *}$, SUSILAWATI ${ }^{3}$, ARIS DOYAN ${ }^{3}$}

${ }^{1}$ Faculty of Agricultural Technology, University of Jambi, Indonesia. Email: ulyarti@unja.ac.id

${ }^{2}$ Faculty of Engineering, University of Jambi, Indonesia. corresponding author: E-mail:

nazarudin@unja.ac.id

${ }^{3}$ Faculty of Teacher Training and Education, University of Mataram, NTB, Indonesia.

Accepted: November $18^{\text {st }}, 2018$. Approved: November $28^{\text {st }}, 2018$. Published: December $6^{\text {st }}, 2018$ DOI: $\underline{10.29303 / j p p i p a . v 5 i 1.174}$

\begin{tabular}{|c|c|}
\hline Key Words & Abstract \\
\hline $\begin{array}{l}\text { Edible Film, } \\
\text { Water Yam, } \\
\text { Cultivars, } \\
\text { Starch } \\
\text { concentration }\end{array}$ & $\begin{array}{l}\text { The purpose of this study was to determine the physical, mechanical and barrier } \\
\text { properties of yam starch edible film. This research used Randomized Block Design } \\
\text { (RAK) grouping the cultivar into 2, white and purple water yam. The starch } \\
\text { concentration used were } 1,33,2,2,67 \text {, and } 3,33 \% \text {.The results showed that the two } \\
\text { cultivars produced similar properties of edible film. The concentration of water } \\
\text { yam starch affected transparency, thickness, water vapour transmision rate (WVTR) } \\
\text { and compressive streght of edible film, but did not affect its solubility in water. The } \\
\text { starch concentration of } 2.67 \% \text { was found to be the most appropriate concentration } \\
\text { which produce edible film with thickness } 0.12 \text { to } 0.13 \mathrm{~mm} \text {, transparency } 12.42 \mathrm{to} \\
13.24 \% / \mathrm{mm} \text {, solubility } 84.36 \text { to } 86.60 \% \text {, water vapor transmission rate } 1.16 \times 10^{-2} \\
\text { to } 1.08 \times 10^{-2} \mathrm{~g} / \mathrm{sec}^{2} \mathrm{~m}^{2} \text {, and compressive strenght } 48.10 \text { to } 49.35 \mathrm{~N} / \mathrm{m}^{2}\end{array}$ \\
\hline
\end{tabular}

\section{INTRODUCTION}

Plastic is still the most food packaging used worldwide. About $39.9 \%$ plastic production is intended for food packaging, which is the biggest market in plastic industry (Plastic Europe, 2017). However, the polymers used for plastic production mostly come from non renewable resources and generates pollution. The alternatives of plastic for food packaging is to utilise renewable and degradable material such as starch to produce bioplastic or edible film. Edible film is thin layer covering a food product which acts as food packaging or food coating and can be eaten along with the food.
Starch is abundant and cheap. It is apromising polymer for edible film due to its thermoplastic characteristic (Jimenez et al., 2012). Starch is colorless, odorless, and tasteless material obtained from starchy tubers by water extraction. Yam is starchy tuber that underutilised in Jambi Province. The tubers are rarely consumed due to its taste and mostly grow in the forest. Yam starch is packed under a compact structure called granules. Yam starch granules are oval, round, ellips or polygonal and have average size 1-100 $\mu \mathrm{m}$. The composition and properties of yam starch depend on the color of the flesh tuber (Nadia et.al., 2014) which is the main criteria to differentiate the cultivars in yam. Although the 
difference in physicochemical and functional properties of the starch among yam cultivars is already known, there is no report on the effect of different properties of yam starch generated from yam cultivars on the characteristic of edible film. White and purple yam are the most abundant yam found in Jambi Province, hence become promising cultivars to be developed and used in current experiment.

The characteristics of starch-originated edible film are not merely depend on the physicochemical properties of the starch. Other factor such as concentration of starch also plays important roles which may affect the properties of edible film (Mali et al., 2004; Fakhoury et al., 2012; Luchese et al., 2017). The objectives of this research were to determine the effect of white and purple yam starch concentration on physical and barrier properties of edible film.

\section{METHODS}

This research was conducted at Laboratory of Agricultural Technology Faculty University of Jambi, Energy and Nano-material Study Centre, University of Jambi and Analytical Laboratory FMIPA University of Sriwijaya. This research used Randomized Block Design with 2 cultivars of water yam starch, 4 levels of starch concentration and 5 repetitions. The cultivars were white and purple water yam whereas the starch concentration were $1,33,2$, 2,67 , and $3,33 \%$ calculated from total film forming solution. The resulted films were analysed for their transparency, thickness, water vapour transmision rate (WVTR), compressive streght and solubility in water.

\section{Starch Extraction (Ulyarti et al., 2016)}

The tubers were washed, peeled, rewashed, and sliced into $2 \mathrm{~mm}$ to $3 \mathrm{~mm}$ slices. The slices were soaked in $15 \%$ table salt for 30 minutes to remove mucus and rewashed for 3 times. The tuber slices were smoothed with the addition of water twice as much as the weigh of the slices using commercial blender. The slurries were passed through 200 mesh filter. The suspension obtained were precipitated for 6 hours. The presipitate was redissolved in water to purify the starch. The wet starch was dried using drying oven at $50^{\circ} \mathrm{C}$ for 6 hours. The dry starch was sieved using 60 mesh filter, sealed packaged and kept at room temperature until further used.

\section{Edible Film Preparation}

An appropriate amount of starch were weighed (1, 2, 3 dan 4 gram) and placed in a beaker glass. The starch was dissolved in aquadest which was added to make exact concentration of $1.33,2,2.67$ and $3.33 \%$ for the total volume of 150 gram filmogenic solution. The solution was subjected to mechanical agitation in a magnetic stirrer and heater at $86^{\circ} \mathrm{C}$ for 10 minutes. Two grams of gliserol was added to the solution. Agitation and heating were continued for another 30 minutes at the same temperature. The filmogenic solution was placed in petri dish and dried in the drying oven at $50^{\circ} \mathrm{C}$ for 24 hours. The films were equilibrated in a desiccator at room temperature and a relative humidity $(\mathrm{RH}) 52 \%$ using saturated $\mathrm{Mg}\left(\mathrm{NO}_{3}\right)_{2}$ salt for 2 days before analysed (Manrich et al., 2017).

\section{Film Thickness (Mendes et al., 2016)}

Film thickness was measured using micrometer at 5 points in the film. The average was reported as film thickness.

\section{Transparency (Pineroz-Hernandez, 2017)}

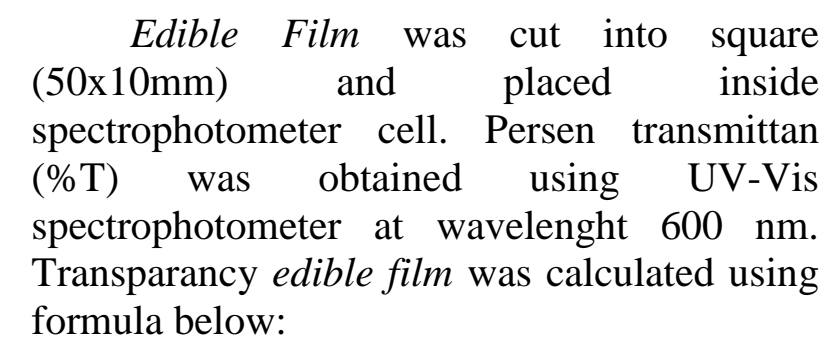

\section{Transparency $=\log \mathrm{T} /$ Thickness Solubility (Gontard et al., 1992)}

Dried filter paper was weighed. Film sample was cut $2 \times 2 \mathrm{~cm}$, weighed $\left(\mathrm{w}_{1}\right)$ and placed in $50 \mathrm{ml}$ of water and soaked for 24 hours. The film was stirred periodically. The solution was filterred using filtered paper which previously dried and weighed. After, the paper was dried at $150^{\circ} \mathrm{C}$ for 24 hours and weighed to measure the amount of undissolved film ( $\left.\mathrm{w}_{2}\right)$. Percent (\%) solubility was calculated using formula below: 
$\%$ Solubility $=\frac{(w 1-w 2)}{w 1} \times 100 \%$

\section{Water Vapour Transmition Rate/WVTR (Pineroz-Hernandez, 2017)}

A tube containing calcium chloride was sealed using edible film produced from this experiments. The tube was weighed and placed inside a desiccator which previously saturated using saturated sodium chloride (RH 75\%). The changes of tube weight over time was noted and plotted as a function of time. WVTR was calculated using formula below:

$$
\begin{aligned}
& \mathrm{WVTR}=\frac{\text { Slope }}{\mathrm{A}} \ldots \ldots \ldots \ldots \ldots \ldots \ldots \ldots \text { (2) } \\
& \text { Where }: \text { WVTR = Water vapour transmition } \\
& \left(\mathrm{g} / \mathrm{m}^{2} / \quad \text { second }\right) \quad \text { Slope in } \\
& \text { gram/second } \\
& \text { A } \quad=\text { The area of the edible film }\left(\mathrm{m}^{2}\right)
\end{aligned}
$$

\section{Compressive Strenght (ASTM, 1997)}

Compressive strenght was measured using LFRA Brookfield Texture Analyzer. The probe was TA $760 \mathrm{~mm}$, trigger $2 \mathrm{~g}$, distance 2
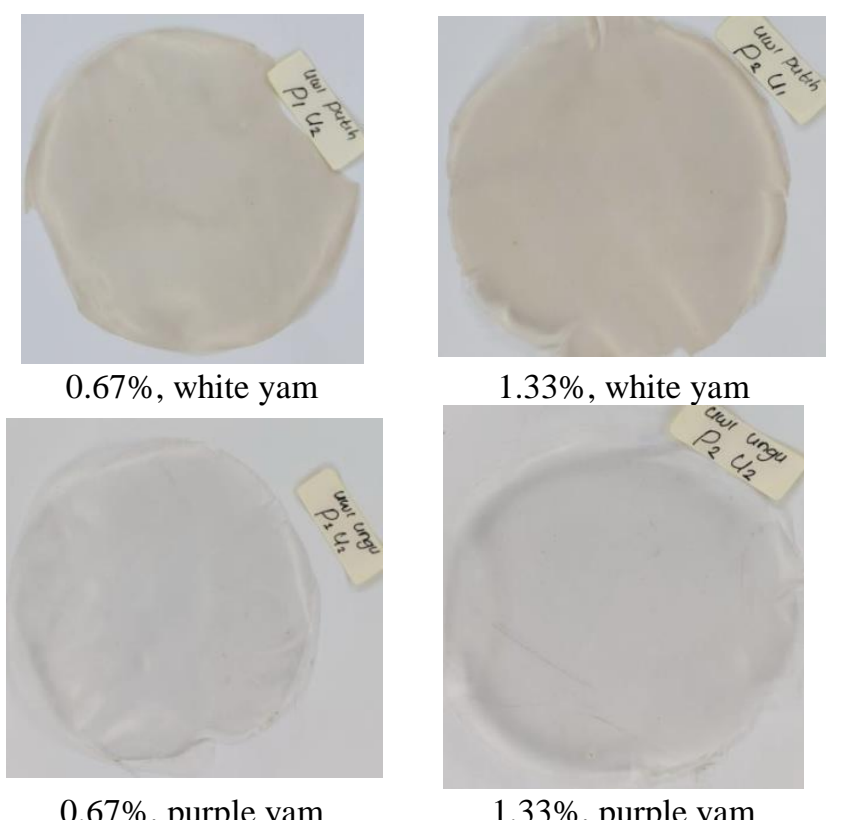

$1.33 \%$, purple yam $\mathrm{mm}$, and speed $2 \mathrm{~mm} / \mathrm{s}$. Film sample $(5 \times 2 \mathrm{~cm})$ was placed under the probe. The probe press the film and the strenght can be read on the screen.

\section{Data Analysis}

The data were analysed using ANOVA and Duncan's New Multiple Range Test (DnMRT).

\section{RESULT AND DISCUSSION Characteristics of White and Purple Yam Edible Film}

The extraction of starch from white and purple yam tuber produced different color of starch. Purple tuber starch is lighter than white tuber starch therefore the color of purple yam starch edible films were lighter than white yam starch edible film (Figure 1). Films produced in this experiments were shiny and glossy at the side in contact with petri dish and dull at the surface in contact with air during drying. This result is similar to the result obtained by Basiak et al (2017).
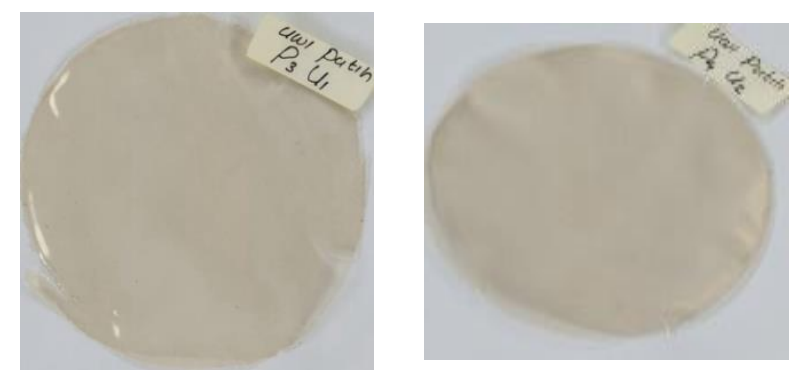

$1.67 \%$, white yam

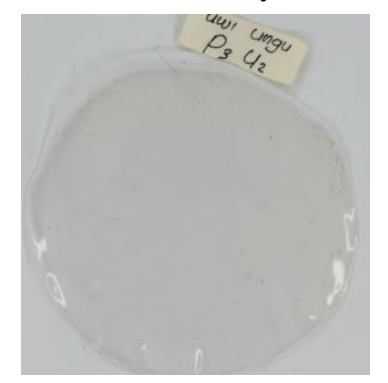

$2 \%$, white yam

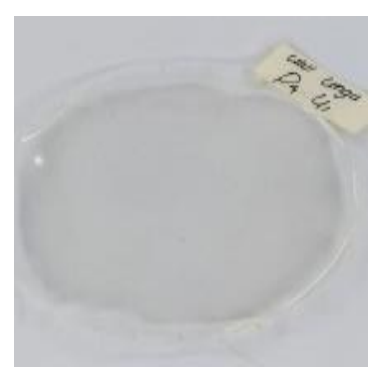

$1.67 \%$, purple yam
$2 \%$, purple yam

Figure 1. Yam Starch Edible Film Produced Using Different Concentration of Starch

Cultivar of yam significantly affect amylose content (Nadia et al, 2014) which further may affect edible film characteristic which depends on the amylose content of the starch. However current experiment showed that edible film characteristics were not affected by cultivar of water yam. Both purple and white water yam starches produced edible films which have similar thickness, transparency, water vapour transmission rate, compressive strenght and solubility in water (Table 1). 
JPPIPA: 5 (1), Januari 2019

Table 1. The Characteristics of Yam Starch Edible Film produced Using Two Different Cultivars and Four Levels Concentration of Starch

\begin{tabular}{|c|c|c|c|c|}
\hline \multirow{2}{*}{ Cultivar } & \multicolumn{4}{|c|}{ Starch Concentration (\%) } \\
\hline & 1,33 & 2,00 & 2,67 & 3,33 \\
\hline \multicolumn{5}{|c|}{ Thickness (mm) } \\
\hline White & $0.10 \pm 0.01 \mathrm{a}$ & $0.12 \pm 0.01 \mathrm{ab}$ & $0.12 \pm 0.01 b c$ & $0.14 \pm 0.00 \mathrm{c}$ \\
\hline Purple & $0.10 \pm 0.00 \mathrm{a}$ & $0.12 \pm 0.02 \mathrm{ab}$ & $0.13 \pm 0.01 b c$ & $0.15 \pm 0.02 \mathrm{c}$ \\
\hline \multicolumn{5}{|c|}{ Transparency $(\% / \mathrm{mm})$} \\
\hline White & $17.77 \pm 2.59 \mathrm{c}$ & $15.11 \pm 1.21 \mathrm{~b}$ & $13.24 \pm 1.20 \mathrm{ab}$ & $12.51 \pm 0.35 \mathrm{a}$ \\
\hline Purple & $16.40 \pm 0.88 \mathrm{c}$ & $14.28 \pm 1.68 \mathrm{~b}$ & $12.42 \pm 1.13 \mathrm{ab}$ & $12.06 \pm 0.88 \mathrm{a}$ \\
\hline \multicolumn{5}{|c|}{ Solubility (\%) } \\
\hline White & $90,84 \pm 0.40 \mathrm{a}$ & $86.54 \pm 1,73 \mathrm{a}$ & $86.60 \pm 0.62 \mathrm{a}$ & $83.65 \pm 1.57 \mathrm{a}$ \\
\hline Purple & $89,05 \pm 0.95 a$ & $86.07 \pm 1,26 \mathrm{a}$ & $84.36 \pm 1.19 \mathrm{a}$ & $84.79 \pm 2.14 a$ \\
\hline \multicolumn{5}{|c|}{ WVTR $($ gram/sec/m²) } \\
\hline White & $\begin{array}{l}1.55 \times 10^{-2} \pm \\
1.65 \times 10^{-3} \mathrm{c}\end{array}$ & $\begin{array}{l}1.58 \times 10^{-2} \pm 4.14 \times 10^{-} \\
{ }^{4} \mathrm{bc}\end{array}$ & $\begin{array}{l}1.16 \times 10^{-2} \pm \\
2.14 \times 10^{-3} \mathrm{a}\end{array}$ & $\begin{array}{l}1.19 \times 10^{-2} \pm \\
6.31 \times 10^{-4} \mathrm{ab}\end{array}$ \\
\hline Purple & $\begin{array}{l}1.43 \times 10^{-2} \pm \\
3.31 \times 10^{-3} \mathrm{c}\end{array}$ & $\begin{array}{l}1.30 \times 10^{-2} \pm 2.07 \times 10^{-} \\
{ }^{4} \mathrm{bc}\end{array}$ & $\begin{array}{l}1.08 \times 10^{-2} \pm \\
4.14 \times 10^{-4} \mathrm{a}\end{array}$ & $\begin{array}{l}1.17 \times 10^{-2} \pm \\
1.65 \times 10^{-3} \mathrm{ab}\end{array}$ \\
\hline \multicolumn{5}{|c|}{ Compressive Strenght $\left(\mathrm{N} / \mathrm{m}^{2}\right)$} \\
\hline White & $36.20 \pm 2.26 \mathrm{a}$ & $53.60 \pm 3.68 b$ & $49.35 \pm^{-5}-44 b$ & $53.05 \pm 2.05 b$ \\
\hline Purple & $34.65 \pm 4.17 \mathrm{a}$ & $49.80 \pm 5.09 \mathrm{~b}$ & $48.10 \pm 6.22 b$ & $42.20 \pm 0.57 b$ \\
\hline
\end{tabular}

The Effect of Starch Concentration on Edible Film Characteristics

Yam starch concentration affected thickness, transparancy, water vapour transmission rate and compressive strenght of edible film $(p<5 \%)$ but did not affect edible film solubility in water (Table 1). The thickness of edible film relates to the amount of total solid in the filmogenic solution (Carneiro, et al., 2009). Present study generated similar results to other studies (Petersson \&Stading, 2005; Kusumawati \& Putri, 2013), that the increase in starch concentration increased thickness of edible film.

Transparency exhibits the amount of lights pass through the film. As shown in Table 1 , the increase in starch concentration significantly decreased transparency of edible film $(p<5 \%)$. Chemical structure of starch affect the amount of crystallinity present in the filmogenic solution. The higher crystallinity gives rise to less transparent edible film. The crystallinity of a starch depend on the origin of the starch (Basiak et al., 2017). Potato starch for example gives more transparent film compare to corn and wheat starch film. Other factor affecting transparency of the film is film thickness, where the thickness decreased transparency. In this experiment, the higher starch concentration in filmogenic solution produced thicker film and hence less transparency film.

Solubility of edible film in water relates to the ability of edible film to pack high water content food. The solubility of yam starch edible film from current experiment showed that the films are very soluble (solubilities are over $80 \%$ ). Further formulation with non polar substance or modification in yam starch is required to decrease the solubility of edible film.

Water Vapour Transmition Rate (WVTR) measures flow of moisture through certain area of a film in a certain time. The value of WVTR showed the ability of the film to pass through moisture. The higher the value of WVTR means the higher the ability of film to pass through moisture which is undesirable for film as packaging material. Current experiment showed that starch concentration affect WVTR significantly $(p<5 \%)$. The increase in starch concentration decreased WVTR due to the increase in film thickness which further limits the ability of moisture to pass through the film (Basuki, et al., 2014).

Compressive strenght is capacity of a material to withstand loads tending to reduce size. It is a parameter to describe how strong it 
is to hold a load. The analysis of variance showed that concentration of starch significantly affect compressive strenght of edible film $(p<5 \%)$. The higher the concentration of starch produced edible film with higher compressive strenght (Table 1). Similar result was reported by Santoso, et al., (2011).

\section{CONCLUSION}

White yam starch and purple yam starch edible films are different in their physical appearance due to the color of their originated starches. Yam starch concentration significantly affect transparency, thickness, water vapor transmission rate and compressive streght $(\mathrm{p}<5 \%)$, but did not affect film solubility in water. Starch concentration $2,67 \%$ is the most appropriate concentration to produce edible film with thickness 0.12 to 0.13 $\mathrm{mm}$, transparency 12.42 to $13.24 \% / \mathrm{mm}$, solubility 84.36 to $86.60 \%$, water vapor transmission rate $1.16 \times 10^{-2}$ to $1.08 \times 10^{-2}$ $\mathrm{g} / \mathrm{sec} / \mathrm{m}^{2}$, and compressive strenght 48.10 to $49.35 \mathrm{~N} / \mathrm{m}^{2}$.

\section{ACKNOWLEDGMENT}

Authors would like to thank to Faculty of Agricultural Technology for research grant under the scheme Hibah PNBP Fakultas 2018.

\section{REFERENCES}

ASTM., 1997. Annual book of ASTM standars. American Sociaty for Testing and Material. Philadelphia.

Basuki. S, Jariyah EK, Hartati DD. 2014. Karakteristik Edible Film Dari Pati Ubi Jalar Dan Gliserol. Jurnal Teknologi Pangan. 8:2. Surabaya.

Basiak E, Lenart A, Debeaufort F. 2017. Effect of Starch Type on the PhysicoChemical Properties of Edible Films. International Journal of Biological macromolecules

http://dx.doi.org/10.1016/j.ijbiomac.20 17.01 .122

Carneiro-da-Cunha, M.G., Cerqueira, M.A., Souza, B.W.S., Souza, M.P., Teixeira, J.A. dan Vicente, A.A. (2009). Physical properties of edible coatings and films made with a polysaccharide from Anacardium occidentale L. Journal of Food Engineering 95: 379-385.

Fakhoury FM, Martelli SM, Bertan LC, Yamashita F, Mei LHI, Queiroz FPC. 2012. Edible Films Made From Blends of Manioc Starch and Gelatine Influence of Different Types of Plastisizer and Different Levels of Macromolecules on Their Properties. LWT - Food Science and Technology, 49, 149-154.

Gontard, N., Guilbert., S., dan Cuq, J.L. 1992. Water and Glycerol as Plasticizer Affect Mechanical and Water Vapor Barrier Properties of an Edible Wheat Gluten Film. J. Food Science. 58(1): 206 - 211. Jimenez A, Fabra MJ, Talens P, Chiralt A. 2012. Edible and biodegradable starch film: a review. Food and Bioprocess Technology, 5(6), 2058-2076.

Kusumawati DH, Putri WDR. 2013. Karakteristik fisik dan Kimia Edible Film Pati Jagung yang Diinkoporasi dengan Perasan Temu Hitam. Jurnal Pangan dan Agroindustri. 1:90-100.

Luchese CL, Frick JM, Patzer VL, Spada JC, Tessaro IC. (2015). Synthesis and characterization of biofilms using native and modified pinhao starch. Food hydrocolloids 45:203-210.

Mali S, Grossmann MVE, Garcia MA, Martino MN, Zaritzky NE. 2014. Barrier, Mechanical, Optical Properties of Plastisized Yam starch Film. Carbohydrate Polymer, 56, 129-135.

Manrich A, Moreira FKV, Otoni CG, Lorevice MV, martins MA, Mattoso LHC. 2017. Hydrophobic Edible Films Made up of Tomato Cutin and Pectin. Carbohydrate Polymers.

http://dx.doi.org/10.1016/j.carbpol.201 $\underline{7.01 .075}$

Nadia, L., Wirakartakusumah, M. A., Andarwulan, N., Purnomo, E. H., Koaze, H., \& Noda, T. (2014). Characterization of physicochemical and functional properties of starch from five yam (Dioscorea Alata) cultivars in Indonesia. International Journal of 
Chemical Engineering and Aplications , 489-496.

Petersson, M. dan Stading, M. (2005). Water vapour permeability and mechanical properties of mixed starchmonoglyceride films and effect of film forming conditions. Food Hydrocolloids 19: 123-132.

Pineroz-Hernandez D, Medina-Jaramillo, C, Lopez-Cordoba A. (2017). Edible cassava starch films for potential use as active food packaging. Food hydrocolloids 63:488-495

Plastic Europe. 2017. Plastics-the facts 2017. An analysis of european plastic production, demand, and waste data. Available from https://www.plasticseurope.org /en/resources/market-data

Santoso B, Hamzah B, Pambayun R. 2011. Pengembangan Edible Film Dengan Menggunakan Pati Ganyong Termodifikasi Ikatan Silang. Vol.22 (2:4).

Ulyarti, Lavlinesia, Fortuna, D., \& Surhaini. (2016b). The study of physical properties of Dioscorea alata's starch from Jambi Province. IJASEIT , 456459. 